\title{
INELASTIC EARTHQUAKE RESPONSE ANALYSIS AND DAMAGE ASSESSMENT OF RETROFITTED RC STRUCTURES USING EXTENDED FIBER MODEL
}

\author{
Kazuyuki IZUNO*, Hirokazu IEMURA**, \\ Yoshikazu YAMADA*** and Toshiki OHKAWA****
}

\begin{abstract}
Retrofitted reinforced concrete structures were modeled using fiber modeling technique extended to include the stress-strain relation of repair material such as grouted epoxy resin or covered steel plates. Earthquake response analysis was then conducted using inelastic hysteretic rules. Effectiveness of seismic retrofit was evaluated through comparison of ductility, hysteretic energy and damage index with the original members. The proposed method was verified by the test results of retrofitted RC beam members. As an application of this method, earthquake response of a strengthened RC bridge pier was simulated. The bridge pier with reinforcements terminated at mid-height was modeled including retrofitting by steel jackets. Thin steel jacket showed higher capacity than thick one because of its larger ductility.
\end{abstract}

Key Words : seismic retrofit, inelastic earthquake response analysis, fiber model, hybrid tests, damage assessment

\section{INTRODUCTION}

Old structures constructed based on old codes sometimes need strengthening for future earthquakes. Moreover, some structures that were rendered nonfunctional due to earthquake damage could be reused after repair or strengthening of the damaged parts. The use of epoxy resin in repaired $\mathrm{RC}$ members and steel jackets in strengthening of $\mathrm{RC}$ structures have been found to be applicable and effective $\mathrm{e}^{1-6)}$. Recently, the collapse of structures during the 1989 Loma Prieta earthquake in U.S.A. brought a large concern on retrofit work, and many researches have been done on this $\operatorname{area}^{7-9)}$. However, a reasonable index to judge whether the structure can be retrofitted or has to be rebuild has not been established yet. In addition, to check whether the retrofitted structures could survive in future earthquakes is not evaluated precisely either. Although many experiments have been done for repaired or strengthened structures, there are only a few analytical studies ${ }^{4,10,11)}$.

In this paper, effectiveness of seismic retrofit for a damaged reinforced concrete structure repaired with grouted epoxy resin or steel jackets was quantified using inelastic response analysis with the force-displacement relationship based on extended fiber model.

* Member of JSCE, M. Eng., Research Associate, Dept. of Civil Engineering, Kyoto University (Yoshida Honmachi, Sakyo-ku, Kyoto 606-01 Japan)

** Member of JSCE, Dr. Eng., Associate Professor, Dept. of Civil Engineering, Kyoto University

*** Member of JSCE, Dr. Eng., Professor, Dept. of Civil Engineering, Kyoto University

**** Member of JSCE, M. Eng., Engineer, Okumura Corporation
The first part of this paper introduces the method of analysis, the second part shows the verification examples using the test results of repaired reinforced concrete specimen, and the last part describes the application of this method to strengthening of bridge piers with reinforcements terminated at mid-height.

\section{SIMPLIFIED PROCEDURE TO QUANTIFY EFFECTIVENESS OF SEISMIC RETROFIT}

Analytical method to calculate ultimate strength of $\mathrm{RC}$ bridge pier was applied to earthquake response analysis of retrofitted RC structures. First, moment-curvature relation at each section of a retrofitted RC structure was derived using the fiber modeling procedure. Then the force-displacement relationship of a single-degree-of-freedom system was derived based on the moment-curvature relationship of each section. Using the forcedisplacement relationship as a skeleton curve, an inelastic hysteretic model was assumed for earthquake response analysis. Lastly, effectiveness of seismic retrofit was evaluated from comparison between inelastic earthquake response during a future earthquake of the retrofitted structure and that of the original.

This simplified method does not calculate precise moment-curvature relation at each time step. Nevertheless, it shows good agreement with. experiments as discussed in the next chapter.

Precise procedure is described in the following.

(1) Fiber model including repair material

Conventional fiber modeling technique for RC structure ${ }^{122}$ can be easily extended to include repair material, such as epoxy resin and steel jacket. The conventional fiber modeling technique calculates 
the stress of each fiber based on the actual location of steel and concrete. The extended fiber model proposed here uses the same equation for the resin, of which real location is unknown, based on the approximated ratio of the resin to the total area of the cross section. The assumed constitutive laws are shown in Fig.1 and Table 1, Fig.1 (a) shows the assumed stress-strain relation of confined and unconfined concrete ${ }^{13)}$. (The plus strain in Fig. 1 means tensile strain.) The reinforcing bars were modeled as shown in Fig.1 (b). A maximum strength plateau was added to a bilinear curve in order to describe the ultimate behavior. Steel jacket was assumed to contribute to the moment-curvature relation of each section as additional reinforcing bars. Hence, the whole concrete of the retrofitted part is confined by the steel jackets. As the grouted epoxy resin usually locates randomly in each section, precise location is unpredictable from outside. Therefore, epoxy resin was defined as an area ratio of its existence in this study. Epoxy resin was assumed to behave partially linear like Fig.1 (c). The confined epoxy resin was assumed to withstand any tensile and compression force, and the unconfined epoxy resin was assumed to crush in compression. Young's modulus of epoxy resin is almost $10 \%$ of concrete, but is larger than concrete in tension. The nominal values for epoxy resin were determined from tensile and compression tests of small test pieces.

Four critical points were determined using this extended fiber model. These were the crack point where cracks of the concrete appear, the yield point where yield of the reinforcing bars occur, the maximum point where crush of the cover concrete occur, and the ultimate point where the core concrete crushes or the strength of the structure decreases to the assumed level. Four linear segments were used to connect these 4 critical points, so that the moment-curvature relation was assumed to be piecewise linear.

( 2 ) Hysteretic model using skeleton curve

The force-displacement relationship was derived based on the moment-curvature relationship of each section. Four points on the moment-curvature relationships were determined to approximate the relationship to piecewise linear in 4 lines.

Using the force-displacement relationship as a skeleton curve, an inelastic hysteretic model was assumed for earthquake response analysis. One of the suitable hysteretic models for RC structures, 3parameter model ${ }^{14)}$, was used in this study. This inelastic model achieves various hysteretic properties using 3 parameters; $\alpha, \beta$ and $\gamma . \alpha$ represents stiffness degradation, $\beta$ represents strength degradation due to hysteretic energy absorption, and

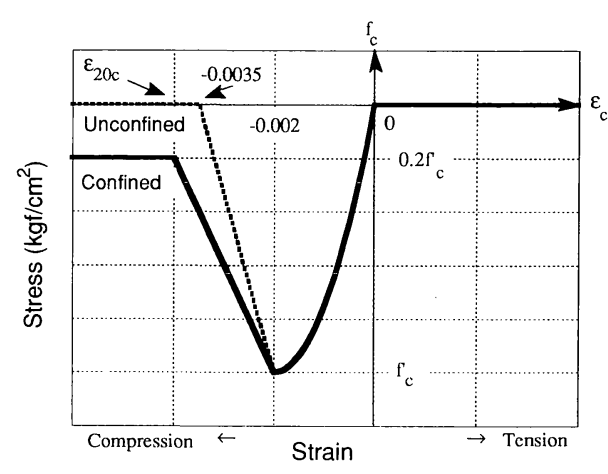

(a) Concrete

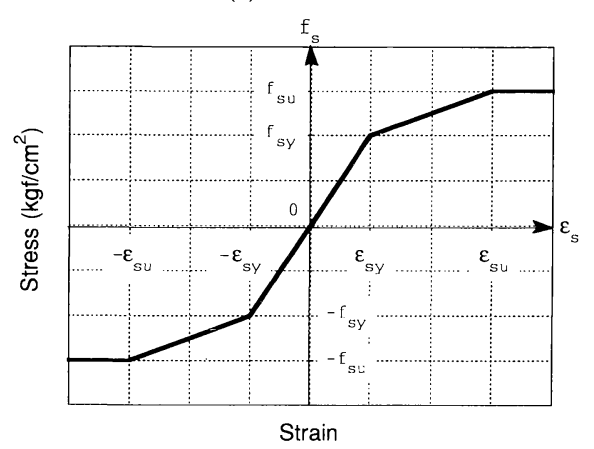

(b) Steel

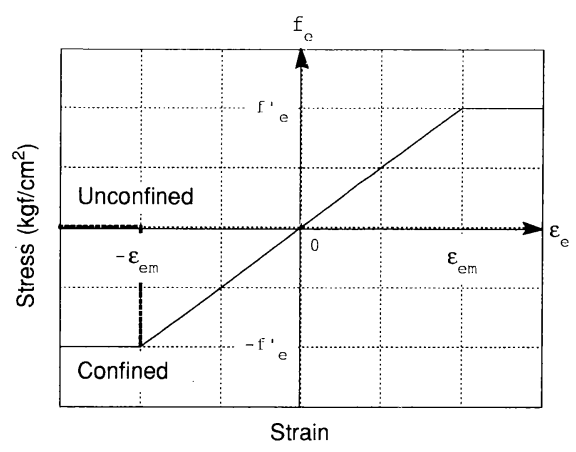

(c) Epoxy resin

Fig.1 Assumed stress-strain relationship

$\gamma$ represents pinching behavior through crack- $^{-}$ opening and crack-closing procedure.

(3) Effectiveness of seismic retrofit

Inelastic earthquake response analysis was carried out for the estimated model using several earthquake records. Then, response of the retrofitted structure during a future earthquake was compared with the original one to evaluate effectiveness of seismic retrofit. Three indices were used to evaluate quantitative effect of seismic retrofit; these were ductility, hysteretic energy and the damage index ${ }^{15)}$. Among the many indices used to evaluate response ${ }^{15-21)}$, ductility, energy absorbing capacity and linear combination of these two 
Table 1 Assumed constitutive laws for concrete, steel and epoxy resin (a) concrete stress-strain relation

\begin{tabular}{|c|c|}
\hline Unconfined & Confined \\
\hline $\begin{array}{c}\text { for } \varepsilon_{c} \leq-0.0035 \\
f_{c}=0\end{array}$ & $\begin{array}{c}\text { for } \varepsilon_{c} \leq \varepsilon_{20 c} \\
f_{c}=0.2 f_{c}^{\prime}\end{array}$ \\
\hline $\begin{array}{c}\text { for }-0.0035<\varepsilon_{\mathrm{c}} \leq-0.002 \\
f_{c}=\left(\varepsilon_{c}+0.0035\right) f_{c}^{\prime} / 0.0015\end{array}$ & $\begin{array}{c}\text { for } \varepsilon_{20 \mathrm{c}}<\varepsilon_{\mathrm{c}} \leq-0.002 \\
f_{c}=f_{c}^{\prime}\left\{1-Z\left(\varepsilon_{c}-0.002\right)\right\}\end{array}$ \\
\hline \multicolumn{2}{|c|}{ for $-0.002<\varepsilon_{\mathrm{c}} \leq 0$} \\
$f_{c}=-f_{c}^{\prime}\left\{2 \varepsilon_{c} / 0.002-\left(\varepsilon_{c} / 0.002\right)^{2}\right\}$ \\
\hline \multicolumn{2}{|c|}{ for $\varepsilon_{\mathrm{c}}>0$} \\
$f_{c}=0$ \\
\hline $\begin{array}{c}Z: \text { parameter for the slope of the falling branch }{ }^{13)} \\
f_{c}^{\prime}=-196 \mathrm{kgf} / \mathrm{cm}^{2}(-19 \mathrm{MPa})\end{array}$ \\
$\varepsilon_{20 \mathrm{c}}$ : strain at which concrete stress becomes $0.2 f_{c}^{\prime}$ \\
\hline
\end{tabular}

(b) steel stress-strain relationship

\begin{tabular}{c} 
for $\varepsilon_{s} \leq-\varepsilon_{s u}, \varepsilon_{s}>\varepsilon_{s u}$ \\
$f_{s}=f_{s u}$ \\
\hline for $-\varepsilon_{s u}<\varepsilon_{s} \leq-\varepsilon_{s y}, \varepsilon_{s y}<\varepsilon_{s} \leq \varepsilon_{s u}$ \\
$f_{s}=\left(\varepsilon_{s}-\varepsilon_{s y}\right)\left(f_{s u}-f_{s y}\right) /\left(\varepsilon_{s u}-\varepsilon_{s y}\right)+f_{s y}$ \\
\hline for $-\varepsilon_{s y}<\varepsilon_{s} \leq \varepsilon_{s y}$ \\
$f_{s}=E_{s} \varepsilon_{s}$ \\
$E_{s}=2,100,000 \mathrm{kgf} / \mathrm{cm}^{2} \quad(0.21 \mathrm{TPa})$ \\
$f_{s y}=3,500 \mathrm{kgf} / \mathrm{cm}^{2} \cdot(0.34 \mathrm{GPa})$ \\
$f_{s u}=5,000 \mathrm{kgf} / \mathrm{cm}^{2}(0.49 \mathrm{GPa})$ \\
$\varepsilon_{\mathrm{sy}}=0.001667$ \\
$\varepsilon_{s u}=0.2$
\end{tabular}

(c) epoxy resin stress-strain relationship

\begin{tabular}{|c|c|}
\hline Unconfined & Confined \\
\hline $\begin{array}{c}\text { for } \varepsilon_{e} \leq-\varepsilon_{m} \\
f_{e}=0\end{array}$ & $\begin{array}{c}\text { for } \varepsilon_{e} \leq-\varepsilon_{m} \\
f_{e}=-f_{e}^{\prime}\end{array}$ \\
\hline \multicolumn{2}{|c|}{$\begin{array}{c}\text { for }-\varepsilon_{m}<\varepsilon_{e} \leq \varepsilon_{m} \\
\qquad f_{e}=E_{e} \varepsilon_{e}\end{array}$} \\
\hline \multicolumn{2}{|c|}{$\begin{array}{r}\text { for } \varepsilon_{e}>\varepsilon_{m} \\
f_{e}=f_{e}^{\prime}\end{array}$} \\
\hline \multicolumn{2}{|c|}{$\begin{array}{l}E_{e}=25,000 \mathrm{kgf} / \mathrm{cm}^{2}(2.5 \mathrm{GPa}) \\
\varepsilon_{m}=0.02 \\
f_{e}^{\prime}=500 \mathrm{kgf} / \mathrm{cm}^{2}(49 \mathrm{MPa})\end{array}$} \\
\hline
\end{tabular}

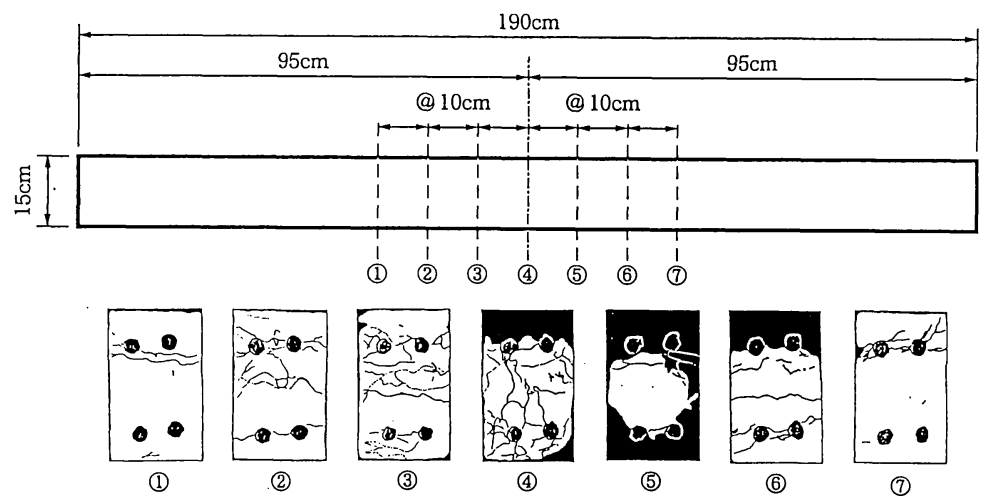

Fig.2 Cross-sectional views of repaired specimen 
are the basic indices. In evaluation of retrofit effect, the maximum restoring force under static loading is the most important checking point. However, ductility and energy absorbing capacities are also important for seismic retrofit in terms of earthquake hazard mitigation.

Ductility is defined as the ratio of the maximum deformation response to the yield deformation. Hysteretic energy, which is calculated as the area of the hysteretic load-deformation responses, has strong correlation with the accumulated damage. Damage index is expressed as ${ }^{15}$

$$
D=\frac{\delta_{m}}{\delta_{u}}+\frac{\beta}{P_{y} \delta_{u}} \int d E
$$

in which, $\beta$ is the damage index, $\delta_{m}$ is the maximum deformation response, $\delta_{u}$ is the defined ultimate deformation, $P_{y}$ is the yield strength, $\int d E$ is the absorbed hysteretic energy and $\beta$ is an empirical coefficient which takes the same value as $\beta$ of the 3 -parameter model. A damage index of more than 1 represents severe damage or collapse.

\section{VERIFICATION EXAMPLES US- ING TEST RESULTS}

\section{(1) Hybrid loading tests of retrofitted RC members}

Seismic behavior of repaired or strengthened RC members by epoxy resin and steel plates was tested using the hybrid testing procedure ${ }^{22)}$, 23). The hybrid experiments are suitable in dealing with complex material such as retrofitted reinforced concrete.

Specimens used were doubly-reinforced concrete members with the dimensions of $100 \mathrm{~mm} \times 150 \mathrm{~mm}$ $\times 1900 \mathrm{~mm}$ Concrete was confined by stirrups every $70 \mathrm{~mm}$. The specimen was simply supported at its both ends and was loaded at its center with an actuator, while the axial load was applied using high-pressure oil built up by pressurizing air. The NS component of the $1940 \mathrm{El}$ Centro record was used as input earthquake motions. First, the specimens were pseudo-dynamically tested to get the damaged specimens. Second, some of them were repaired by grouted epoxy resin ${ }^{24)}$ or covered with steel jackets. The damaged part (mainly around the center of the beam) was sealed with epoxy bond, then epoxy resin was grouted into cracks at a low pressure. After that, steel plate was bonded to the damaged parts with epoxy bond for the steel jacketing method. Then, the repaired specimens and the unrepaired damaged specimens were tested again using the same input motions to see effectiveness of seismic retrofit.

\section{( 2 ) Comparison between experimental and analytical results}

The models used in the experiments mentioned above were numerically simulated using the proposed analytical procedure for verification.

A model of the specimen was divided into 50 sections and each section was divided into 52 fibers. Repair had been done at the mid-span of the simple beam. Area of epoxy resin in each section was determined from the cross-sectional views of the repaired specimen cut into pieces after the loading tests shown in Fig.2. In the figure, the shaded area and thin lines are epoxy resin used for repair, and the 4 circles are the reinforcing bars. Epoxy resin exists quite randomly in each section, which shows difficulty in modeling this section exactly using conventional fiber modeling technique or the finite element method. Therefore, the ratio of epoxy resin to the total area of each section was evaluated and was used as an average ratio of epoxy resin in each fiber; i.e. , the estimated area of each fiber was assumed as epoxy resin. As in this figure, epoxy resin was assumed to take $50 \%$ of the section area at the center span and linearly decreased to $0 \%$ at $30 \mathrm{~cm}$ from the center in each direction.

a) Force-deformation relation

First, force-deformation relation was compared between experiment and analysis shown in Fig.3. The experimental result for the original member had been derived from the static loading test while the results for the retrofitted members had been estimated from the skeleton curves of the hybrid loading tests. The ultimate point was defined to have the same strength as the yield point (where the reinforcing bars yield) or the $80 \%$ of the maximum restoring force.

The relation for the original specimen, the solid lines in Fig.3, shows good agreement between experiment and analysis except for the small range of deformation. As the tensile strength of concrete was neglected as shown in Table 1, the yield point of the reinforcing bars was underestimated. Assuming the tensile strength of concrete would improve the matching of analytically obtained relation with the experimental result in the small range of deformation. For the retrofitted specimens (the broken lines and the dotted lines in Fig.3), the analysis underestimated the strength compared with the experiments. Considering that the skeleton curves of the dynamic loading tests usually show higher strength, the analytically obtained force-deformation relation could give reasonable estimation.

Comparing the analytical force-deformation relation between the original and the retrofitted members, the retrofitted members showed higher yield strength and higher maximum strength than the original. Furthermore, the initial stiffness of the 


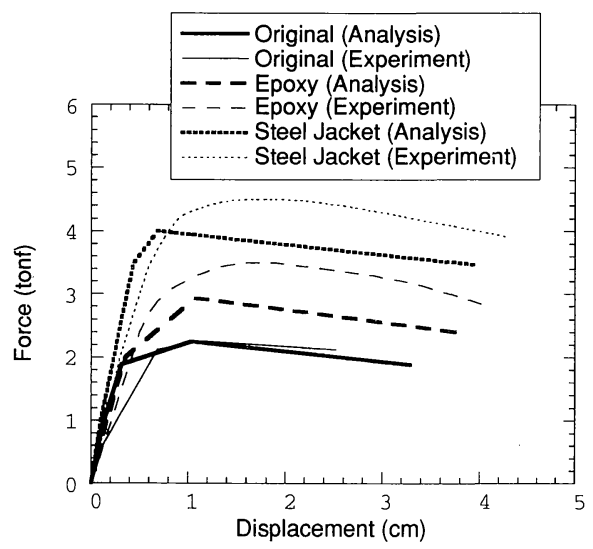

Fig.3 Force-displacement relation of analytical and experimental results

retrofitted member with grouted epoxy resin became smaller than the original while that of the retrofitted member with steel jackets became larger. These phenomena were also shown from the experimental results.

b) Hysteretic load-deformation responses

Fig.4 shows one of the results comparing the experimental and analytical hysteretic responses before and after repair work with epoxy resin. Analytically obtained hysteretic load-deformation responses successfully simulated the experimental results. Repaired specimens became stiffer than originals because the grouted epoxy resin has higher tensile strength than concrete. The evaluated maximum responses showed similar values as the experiments. The only significant difference was the behavior during strong earthquake motions such as the El Centro record with the maximum acceleration scaled to 300 gal. The analytical results showed stable hysteretic responses even for the strong input motions while the specimen collapsed in the experiments. This is due to the assumption of completely retrofitted steel materials used in the analysis, but in reality the buckled reinforcing steel bars in the specimen were ineffective. This simplified analysis estimates seismic response time histories of the total pier. On the contrary, response time histories of each fiber nor status of steel at each time step are not evaluated in this analysis. Degrading Young's modulus of damaged steel might be needed to consider precisely the effect of the first loading to the second loading.

c) Indices for energy dissipation and damage

Fig.5 compares analytically obtained hysteretic energy with experimentally obtained hysteretic energy and Fig. 6 compares their corresponding damage indices. The dashed line means the same values were obtained from both the experiments and the analysis. All dots scattered around this line, which shows the estimated hysteretic energy and damage index were in good agreement with the experimental results. Hysteretic energy of original specimens was estimated to an accuracy within $10 \%$ for weak input motions. The damage indices were also estimated with errors of only 0.1-0.2. However, this analysis underestimated hysteretic energy $20-30 \%$ for strong input motions because of its stable hysteretic responses as discussed before. For repaired specimens, ratio of epoxy resin to concrete in each fiber was determined from only one specimen shown in Fig.2, and the identical values were assumed for all the repaired specimens. Therefore, errors in estimations were larger than the original specimens. However, the judgement, from the damage index, whether the specimen will collapse or not; i.e., the damage index overcomes 1.0 or not, was the same for all the specimens.

\section{APPLICATION TO BRIDGE PIER WITH TERMINATED REIN- FORCEMENT}

Some old bridge piers constructed under old codes have insufficient anchorage length and termination of their main reinforcement ${ }^{6}$. These structures might suffer a brittle shear failure at midheight where the reinforcement terminated and need strengthening for future earthquakes. Use of steel jackets has been found applicable from experiments to prevent brittle failure ${ }^{6)}$. The proposed analytical method was then applied to evaluate effect of strengthening for the bridge piers with reinforcements terminated at mid-height.

\section{(1) Model for simulations}

T-shape bridge pier of $13 m$ high shown in Fig.7 was modeled to have the terminated main reinforcement. The cross section has rectangle shape of $3.5 m \times 3.0 m$. This pier was designed basically on the specification of highway bridge pier ${ }^{25)}$ and $30 \%$ of the main reinforcing bars were intentionally terminated at $3.0 \mathrm{~m}$ high to model an old type pier. Then, the pier was divided into 50 sections and the moment-curvature relationship of each section shown in Fig.8 (a) was calculated using more than 120 fibers. The ultimate state was defined as the crush of the core concrete because of its simple calculation. This figure shows that crushing may occur at $3.0 \mathrm{~m}$ high where the reinforcement terminated.

Four types of steel jackets were considered: (A) $1 \mathrm{~mm}$ thick plate which covers only at midheight; (B) $2 \mathrm{~mm}$ thick plate which covers only at midheight; (C) $1 \mathrm{~mm}$ thick plate which covers from bottom to midheight; and (D) $2 \mathrm{~mm}$ thick plate 


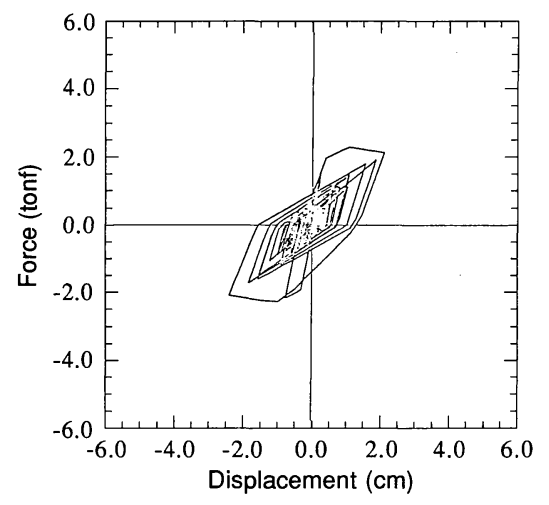

(a) Analytical result for original specimen

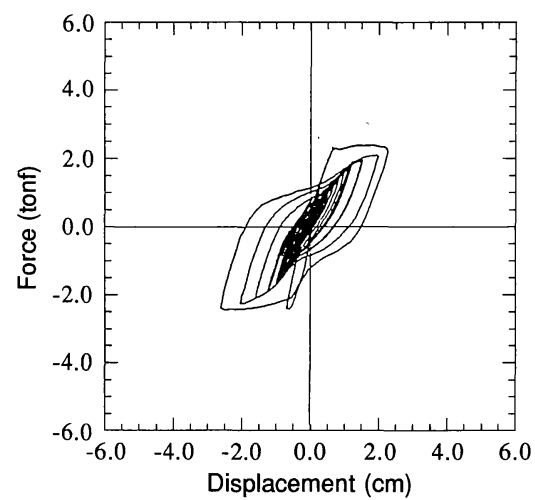

(a) Experimental result for original specimen

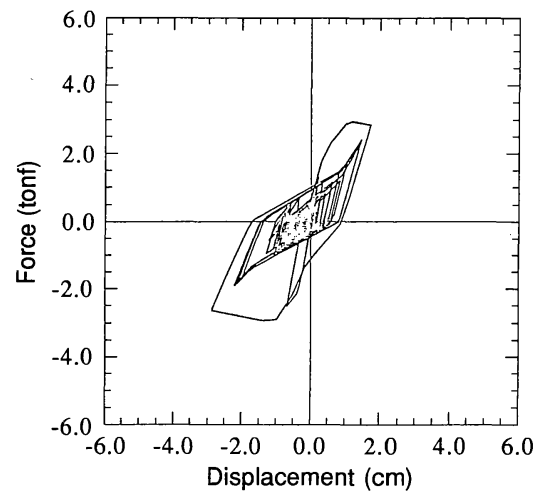

(b) Analytical result for repaired specimen

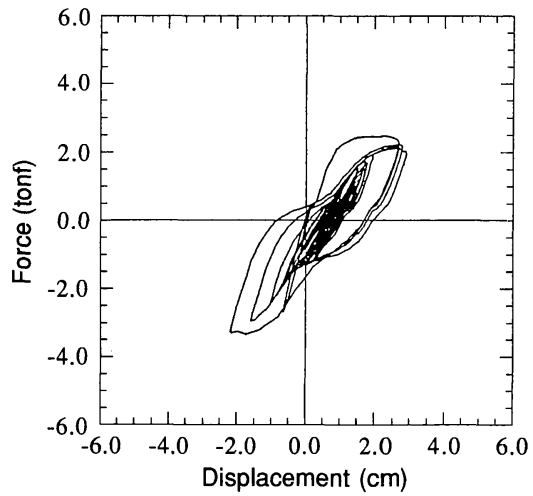

(b) Experimental result for repaired specimen

Fig.4 Comparison of hysteretic loops between analysis and experiment for original and repaired specimens

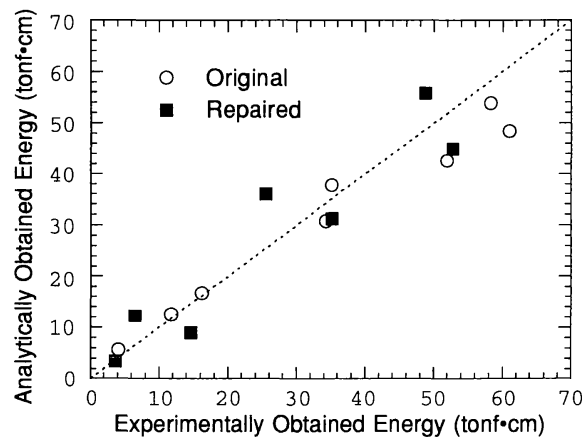

Fig.5 Comparison between analytical and experimental absorbed hysteretic energy during experiments

which covers from bottom to midheight. For (A) and (B), the pier was covered with the steel jackets only at the midheight where the reinforcing bars had been terminated, i.e., the retrofitted pier has the steel belt at midheight and the no-strengthened pier bottom. The vertical width of the steel jackets for (A) and (B) was set to have the same length as

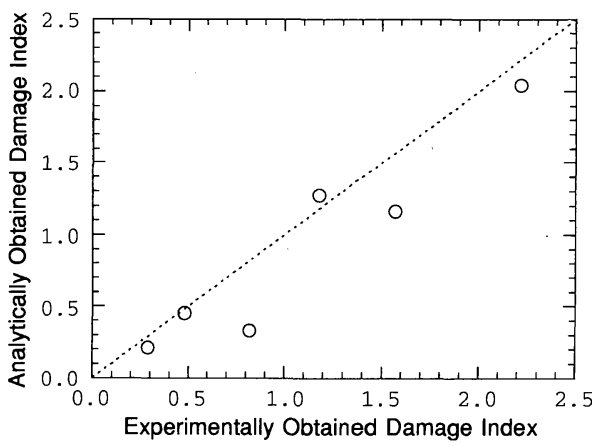

Fig.6 Comparison of damage indices obtained by analyses and experiments

the pier width $(=3.5 m)$ based on Ref. 6. Steel jackets were assumed to bonded perfectly to the concrete surface through the seismic response regardless of epoxy resin bond. Figs.8 (b) and 8 (c) show the moment-curvature relationships for the strengthened bridge pier with steel jackets for cases (A) and (B). Thicker steel jackets gave smaller 


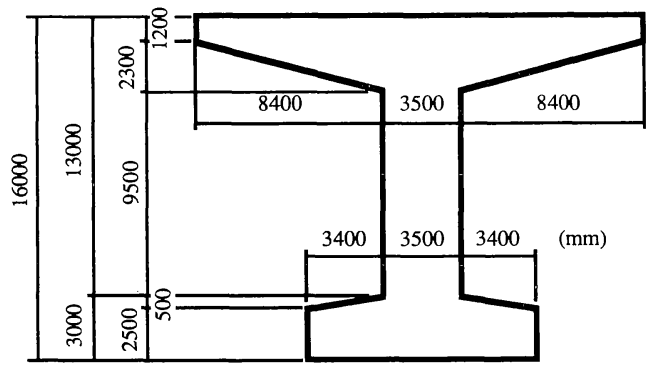

Fig.7 T-shape bridge pier model used for the simulations,based on Ref.25)

curvature at the section where the reinforcement had been terminated. The critical place moved from the mid-height to the bottom, which means the strengthening had been done effectively. Note that the pier bottom of $(\mathrm{A})$ and $(\mathrm{B})$ had not been retrofitted.

\section{( 2 ) Force-deformation relation}

The calculated force-deformation relationship for the pier top is shown in Fig.9. The solid line is for the original pier, the dashed thin line is for (A) the strengthened pier with $1 \mathrm{~mm}$ thick steel jackets only at midheight; the dotted thin line is for (B) the strengthened pier with $2 m m$ thick steel jackets only at midheight; and the dashed thick line is for (C) the strengthened pier with $1 \mathrm{~mm}$ thick steel jackets from bottom to midheight; the dotted thick line is for (D) the strengthened pier with $2 \mathrm{~mm}$ thick steel jackets from bottom to midheight. The pier bottom where no strengthening had been done became the critical place for the strengthened piers for $(\mathrm{A})$ and (B). Therefore, the ductility decreased because of the stiffer structure with the same ultimate strength as the original. For (C) and (D), both the ductility and the maximum restoring force increased for the retrofitted piers comparing with the original one. The pier with $2 \mathrm{~mm}$ jackets of case (D) showed larger restoring force compared to the $1 \mathrm{~mm}$ jackets of case (D), however, it showed smaller ductility.

\section{(3) Inelastic Earthquake response}

The inelastic earthquake response analysis was done using the Type 3 earthquake which was recommended in the Japanese seismic $\operatorname{code}^{26)}$ for the soft ground. Though the original structure may collapse in shear failure, the proposed analytical method cannot determine the failure mode nor the dynamic behavior of each section at each time step because it considers the structure as an singledegree-of-freedom system. Therefore, the parameter $\gamma$ in the 3-parameter hysteretic model, which represents pinching effect, was set to 0.5 for the original structure to express its shear behavior. The hysteretic responses of the original pier and the partially retrofitted piers of $(A)$ and $(B)$ for the 3

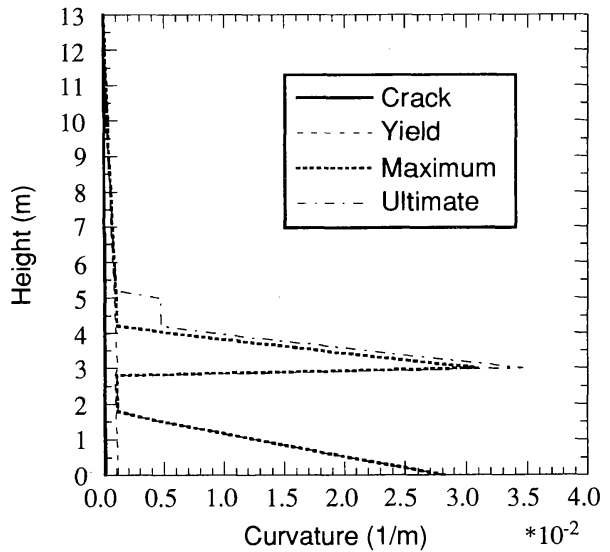

(a) Original

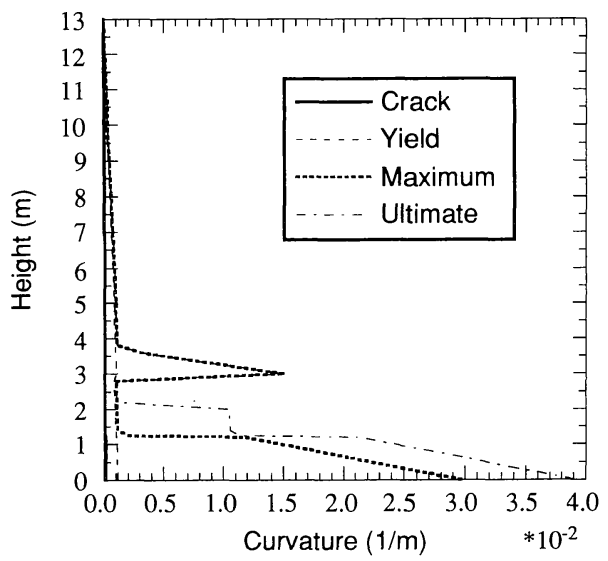

(b) Strengthened with $1 \mathrm{~mm}$ steel jackets - case (A)

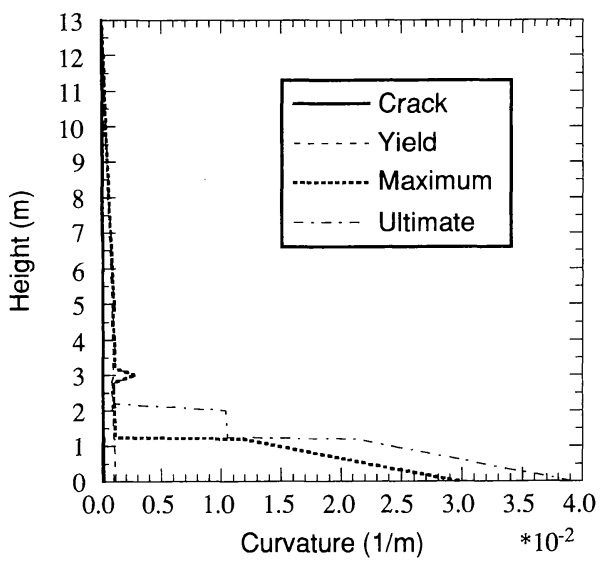

(c) Strengthened with $2 \mathrm{~mm}$ steel jackets - case (B)

Fig.8 Moment-curvature relation at each section of the bridge piers 


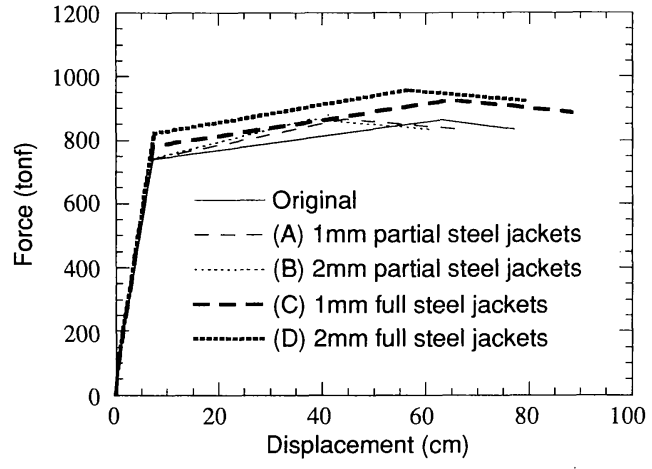

Fig.9 Estimated force-displacement relation of original and strengthened bridge pier

times larger input acceleration as the design code are shown in Fig.10. Strengthened structure showed more stable responses than the original.

The absorbed hysteretic energy, the damage index of the original and strengthened bridge piers including the other indices are shown in Table 2. Some indices showed similar values for the original and retrofitted structures. All ductility factors remained about 1 , and all the ratios of hysteretic energy to the total input energy were 0.6 . Though the absorbed energy became smaller for the partially strengthened structures of (A) and (B), they showed larger values for the damage index because of their low ductility. Furthermore, the retrofitted pier with $2 \mathrm{~mm}$ thick steel jackets showed larger damage index than $1 \mathrm{~mm}$ thick steel jackets for the same reason.

The fully retrofitted piers of (C) and (D) showed smaller displacement responses and larger restoring forces, which means they became stiffer than the original. Though the retrofitted piers showed smaller damage indices, the retrofitted pier with $2 \mathrm{~mm}$ thick steel jackets of case (D) showed larger damage index than $1 \mathrm{~mm}$ thick steel jackets of case (C) because of its lower ductility.

Effectiveness of thinner jackets was verified, of which thickness is thick enough to change the critical place from the midheight to the pier bottom. Strengthening at the pier bottom may also be needed to satisfy ductility requirement as in cases (C) and (D). The retrofitted piers in cases (A) and (B) showed more stable hysteretic responses than the original which means less potential of seismic vulnerability, however, their damage indices became larger compared with the original. The failure mode of the structure could not be evaluated with the damage index.

(4) Sensitivity analysis on quantity of epoxy resin

Amount and precise location of epoxy resin is

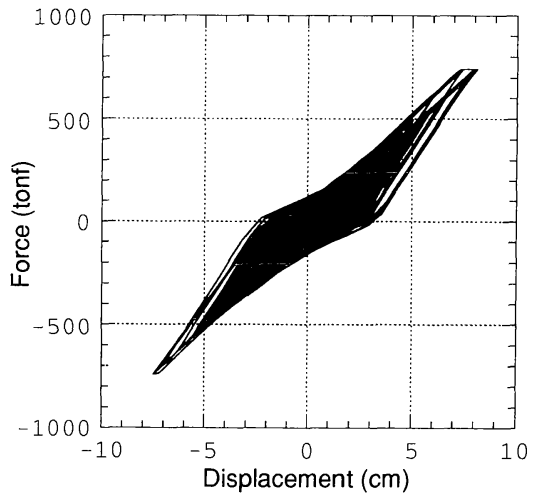

(a) Original

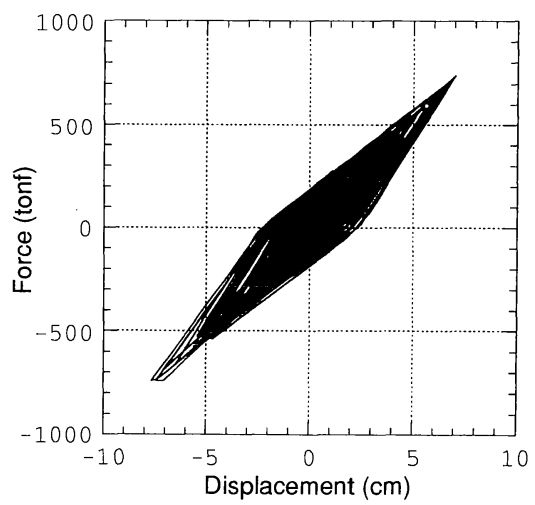

(b) Strengthened with $1 \mathrm{~mm}$ steel jackets - case (A)

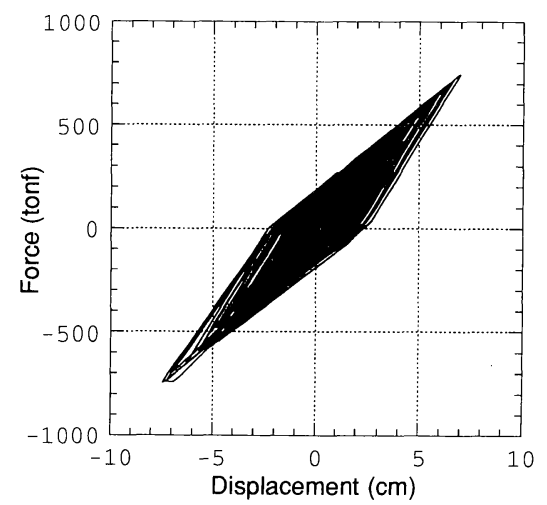

(c) Strengthened with $2 \mathrm{~mm}$ steel jackets - case (B)

Fig.10 Simulated hysteretic responses of original and strengthened bridge piers

hard to probe from outside. Therefore, sensitivity was studied on quantity of grouted epoxy resin. $10 \%$ and $20 \%$ of each strengthened section was assumed to be grouted with epoxy resin. These simulations may represent the case that the pier already had some cracks to be repaired at midheight, or steel jackets were bonded to the pier with epoxy resin. The thickness of the steel jackets was selected to $1 \mathrm{~mm}$ which covers from the bottom 
Table 2 Response of original and strengthened bridge pier

\begin{tabular}{|l|r|l|l|l|r|}
\hline & Original & $\begin{array}{l}\text { (A) Partially } \\
\text { Strengthened } \\
\text { with 1 mm } \\
\text { steel jackets }\end{array}$ & $\begin{array}{l}\text { (B) Partially } \\
\text { Strengthened } \\
\text { with 2 mm } \\
\text { steel jackets }\end{array}$ & $\begin{array}{l}\text { (C) Fully } \\
\text { Strengthened } \\
\text { with 1 mm } \\
\text { steel jackets }\end{array}$ & $\begin{array}{l}\text { (D) Fully } \\
\text { Strengthened } \\
\text { with 2 mm } \\
\text { steel jackets }\end{array}$ \\
\hline Ductility Factor; $\mu$ & 1.12 & 1.09 & 1.09 & 1.03 & 0.98 \\
\hline Maximum Displacement (cm) & 8.1 & 7.7 & 7.5 & 7.6 & 7.3 \\
\hline Maximum Force (tonf) & 743.1 & 743.3 & 743.7 & 781.6 & 804.0 \\
\hline Maximum Velocity (kine) & 60.7 & 58.2 & 57.5 & 59.7 & 60.3 \\
\hline Damage Index & 0.52 & 0.55 & 0.60 & 0.41 & 0.42 \\
\hline 1st term of Damage Index & 0.11 & 0.11 & 0.12 & 0.09 & 0.09 \\
\hline 2nd term of Damage Index & 0.42 & 0.44 & 0.48 & 0.32 & 0.33 \\
\hline Hysteretic Energy; WH (tonf·cm) & 47573 & 43959 & 43452 & 44226 & 42853 \\
\hline Total Input Energy; E (tonf·cm) & 79463 & 72789 & 71818 & 73792 & 71825 \\
\hline WH/E & 0.599 & 0.604 & 0.605 & 0.599 & 0.597 \\
\hline
\end{tabular}

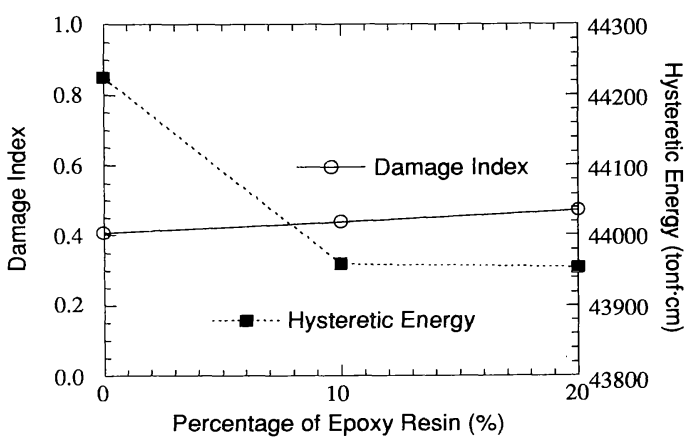

Fig.11 Damage index and absorbed hysteretic energy according to amount of epoxy resin

to the midheight (case C). Fig.11 shows the damage index and absorbed hysteretic energy for each case. As epoxy resin increases, the damage index also increases and the hysteretic energy decreases. However, the difference is smaller than $1 \%$ for the hysteretic energy and 0.07 for the damage index. Considering the large ratio of $20 \%$ for epoxy resin in each section, the effect of amount of epoxy resin to seismic behavior of strengthened bridge pier is small enough to neglect it, if it is plenty enough to bond the steel jackets perfectly to the concrete surface.

\section{CONCLUSIONS}

Analytical methods for inelastic earthquake response and damage assessment of retrofitted RC structures was studied. Main conclusions obtained are as follows:

1. Analytical methods for inelastic earthquake response analysis was proposed using the skeleton curves obtained from the fiber model extended to include repair materials.

2. Analytically obtained hysteretic responses, absorbed hysteretic energy and damage indices were in good agreement with the experimental results. The hysteretic responses of both original and retrofitted RC members can be modeled by the proposed method with high accuracy.

3. Aseismic behavior of the strengthened bridge pier was simulated, and effectiveness of thinner steel jackets was verified. Existence of epoxy resin in strengthened bridge pier with steel jackets was negligible for dynamic behavior if the steel jackets had been bonded perfectly to the concrete surface during earthquake response.

\section{ACKNOWLEDGEMENTS}

The authors thank Mr. Shinji Nakanishi of Kyoto University for his aid in the experiments. We are also grateful to Mr. Susumu Inoue of Kyoto University and Mr. Tetsuo Hirose of Hanshin Highway Public Corporation who helped us in making suitable bridge pier model. The help by Dr. William Tanzo of Saitama University in preparing this paper is also acknowledged.

\section{REFERENCES}

1) Yamamoto, Y. and Imai, H. : A case study on repair effect of an earthquake-damaged $\mathrm{R} / \mathrm{C}$ structure repaired by injecting epoxy resin, Proc. of the 30th Symposium on Structural Engineering, pp. 153-161, 1984 (in Japanese).

2) Wight, J. K., ed. : Earthquake Effects on Reinforced Concrete Structures, U.S.-Japan Research, SP-84, ACI, U.S.-Japan Research, 1985.

3) French, C. W., Thorp, G. A. and Tsai, W.-J. : Epoxy repair techniques for earthquake damage, ACI Structural Journal, Vol. 87, No. 4, pp. 416-424, 1990.

4) Jordan, R. M. and Kreger, M. E. : Evaluation of strengthening schemes and effects on dynamic characteristics of reinforced concrete frames, Proc. of the 4th U. S. 
National Conference on Earthquake Engineering, Vol. 3, pp. 363-372, 1990.

5) Seible, F. and Priestley, M. J. N. : Damage and performance assessment of existing concrete bridges under seismic loads, Proc. of the 1st U.S.-Japan Workshop on Seismic Retrofit of Bridges, pp. 203-222, 1990.

6) Kawashima, K., Unjoh, S. and Iida, H. : Seismic inspection and seismic strengthening of reinforced concrete bridge piers with termination of main reinforcement at mid-height, Proc. of the 1st U.S.-Japan Workshop on Seismic Retrofit of Bridges, pp. 251-279, 1990.

7) Buckle, I. G. and Mayes, R. L. : Seismic retrofit of bridges using mechanical energy dissipators, Proc. of the 4th U. S. National Conference on Earthquake Engineering, Vol. 3, pp. 305-314, 1990.

8) Mahin, S. A. and Moehle, J. P. : Assessment and retrofit research for multi-level, multi-column bents, Proc. of the 1st U.S.-Japan Workshop on Seismic Retrofit of Bridges, pp. 175-186, 1990.

9) Ohuchi, H., Matsuda, T. and Goto, Y. : A study on the Cypress Viaduct collapse and seismic performance of a retrofitted bent, Structural Eng. / Earthquake Eng., Japan Society of Civil Engineers, Vol. 9, No. 1, pp. 65-76 (Proc. of JSCE, No. 446/I-19, pp. 77-88), 1992.

10) Badoux, M. and Jirsa, J. O. : Steel bracing of RC frames for seismic retrofitting, Journal of Structural Engineering, ASCE, Vol. 116, No. 1, pp. 55-74, 1990.

11) Miranda, E. and Bertero, V. V. : Post-tensioning technique for seismic upgrading of existing low-rise buildings, Proc. of the 4th U. S. National Conference on Earthquake Engineering, Vol. 3, pp. 393-402, 1990.

12) Park, R. and Paulay, T. : Reinforced Concrete Structures, John Wiley \& Sons, New York, 1975.

13) Kent, D. C. and Park, R. : Flexural members with confined concrete, Journal of the Structural Division, ASCE, Vol. 97, ST 7, pp. 1969-1990, 1971.

14) Park, Y. J., Reinhorn, A. M. and Kunnath, S. K. : Seismic damage analysis of reinforced concrete buildings, Proc. of the 9th World Conference on Earthquake Engineering, Vol. VII, pp. 211-216, 1988.
15) Park, Y. J., Ang, A. H.-S. and Wen, Y. K. : Seismic Damage Analysis and Damage-Limiting Design of RC Buildings, University of Illinois, No. 516, October 1984.

16) Park, Y. J. and Ang, A. H.-S. : Mechanistic seismic damage model for reinforced concrete, Journal of Structural Engineering, ASCE, Vol. 111, pp. 722-739, 1985.

17) Japan Road Association : Manual for Seismic Countermeasure Methods for Roads against Earthquakes, 1988 (in Japanese).

18) Dong, W., Chiang, W.-L., Shah, H. C. and Wong, F. S. : Failure possibility of existing buildings, Civil Engineering Systems, Vol. 6, No. 4, pp. 170-179, 1989.

19) Dipasquale, E. and Cakmak, A. S. : On the relation between local and global damage indices, NCEER, No. 890034, 1989.

20) Kawashima, K. and Unjoh, S. : An inspection method of seismic vulnerability of existing highway bridges, Structural Eng. / Earthquake Eng., Japan Society of Civil Engineers, Vol. 7, No. 1, pp. 143-150 (Proc. of JSCE, No. 416/I-13, pp. 155-162), 1990.

21) Nishimura, A. : Judgement of the structural integrity of bridge foundation with the percussion test for structure response, Proc. of the 8th Japan Earthquake Engineering Symposium, pp. 2163-2168, 1990 (in Japanese).

22) Yamada, Y., Iemura, H. and Izuno, K. : Hybrid experiments on repaired RC members subjected to earthquake motion, Natural Disaster Science, Vol. 9, No. 2, pp. 97-114, 1987.

23) Izuno, K., Yamada, Y. and Iemura, H. : Hybrid experiments on repaired RC members considering axialforce effects, Proc. of the 9th World Conference on Earthquake Engineering, Vol. VII, pp. 365-370, 1988.

24) Sho-Bond Construction Co. Ltd. : The BICS technique, Sho-Bond Catalog, 1981.

25) Hanshin Highway Public Corporation : General Figures for Reinforced Concrete Structures, 1991.

26) Japan Road Association : Seismic Design Code, Specifications for Highway Bridges in Japan, Part V, 1990 (in Japanese).

(Received June 8, 1992)

\section{$\mathrm{RC}$ 構造物の耐震補強効果に関する数值解析評価手法の提案 伊津野和行・家村浩和・山田善一・大川俊紀 \\ 本研究では, 耐震補強に用いられるエポキシ樹脂や補強鋼板等の構成則も考慮した ファイバーモデルと, 非線形履歴復元力モデルを用いた地震応答解析から, RC 構造物 の耐震補強効果を定量的に評価する手法を提案した。 そのうえで, 補修されたRC 部材 のハイブリッド実験結果との比較から, 手法の妥当性を検討した. また, 主鉄筋の段落 し部が補強されたRC 橋脚に本手法を適用し，耐震補強効果の数値計算例を示した。}

